I Universidade Federal de Goiás (UFG), Faculdade de Informação e

Comunicação, Goiânia, GO, Brasil

rafaelcoelho@ufg.br

https://orcid.org/oooo-0002-3947-2908

Rafael Franco Coelho'

\title{
THE DIGITAL VILLAGE PROJECT: EXAMINING THE SOCIAL ORGANIZATION OF XAVANTE MEDIA PRODUCTION IN CENTRAL BRAZIL ${ }^{1}$
}

\section{BRIEF INTRODUCTION TO THE A'UWĒ XAVANTE}

According to historical sources, the A'uwe Xavante have inhabited the central highlands of Brazil since the eighteenth century. They migrated to this region - officially and legally considered part of Amazonia - moving from the north of the state of Goiás, between the Tocantins and Araguaia rivers, before eventually settling in the state of Mato Grosso.

Xavante is the Portuguese name used by Brazilians to identify this indigenous group. The tribe identifies and names itself in its own language as A'uwe, translatable as people, human or person. Their language belongs to the Jê ethnolinguistic family, pertaining to the Macro-Jê trunk.

A'uwe or Xavante society is organized through multiple dualist systems that determine social organization, kinship, marriage and politics through a set of intersecting 'moieties'. One of these segments is constituted by the clans that divide the community into two exogamous and patrilineal moieties: the Pö'redza'õnõ (tadpole) moiety and the Öwawē (much-water) moiety. Marriages are only celebrated between members of the two moieties, and clan membership is passed on from father to son, which means that mothers always belong to the clan "of the other moiety."

According to Graham (I993: 722) "the dualist Xavante philosophy organizes people into other types of moieties." The A'uwe Xavante divide themselves according to hierarchically-organized age groups, starting with the oldest and 
terminating with the youngest. There are eight age groups in all, four for each moiety. The age group system is made up of those who lived together in the phase prior to initiation rituals, a period spanning around five years, in the "house of those who are single" - Hö, in the Xavante language. Not only do they take part in initiation rites together, they are also married together in a collective ceremony.

\section{THE DIGITAL VILLAGE PROJECT}

The goal of the Digital Village Project is to promote education in media use among the A'uwe Xavante of Sangradouro village, offering workshops on blogmaking, animated film, documentary video and posters. Workshop activities include filming, recording, documentation, and the written and audiovisual description of the cultural practices of the A'uwē Xavante, as well as the subsequent distribution, publication and transmission of the material produced via the internet. The purpose of the workshops the project team gave was to offer education and training to the youth of the village so that they could acquire the skills needed to produce their own media. In global terms, our purpose was to enable the digital inclusion of this indigenous ethnic group.

The Indigenous Land (T.I.) Xavante of Sangradouro covers a surface area of approximately 100,000 hectares, and is inhabited by I,660 people, distributed among 25 villages. Sangradouro is the main village and the largest, founded in 1957 by a group coming from the Xavante of Parabubure Indigenous Land, led by Pedro Toroibu. ${ }^{2}$ The village is located $1.5 \mathrm{~km}$ from the BR-070 interstate highway ( $\mathrm{km} \mathrm{225}$ ), some 53km distance from the town of Primavera do Leste. According to the last census, carried out in 20 Io by the National Indian Foundation (FUNAI), the population of Sangradouro village was 882 people. Near to Sangradouro village is a village belonging to the Bororo ethnic group, as well as a Salesian mission. The mission is a mere 700 meters from the village, and comprises a church and a residential building that accommodates priests, nuns and occasional guests. Next to the mission is a health center and the San José Indian School, which offers primary and secondary school education.

A large proportion of our workshops were held in the computer laboratory of the Indian School in Sangradouro village. The Sangradouro Indian School was founded in I 957 by the Salesians. From I 957 to I 974 , it functioned as a boarding school. From I 975 until I990, it no longer operated as a boarding school but continued to be managed by the Salesians. In I99I, the school administration was switched over to the Brazilian Ministry of Education. Finally, since 2006, all its teachers and the school principal have been Xavante. The center has a computer laboratory with around 20 computers, internet access and an A'uwe Xavante computer instructor called Natal. At present, the laboratory is used for teaching and educational activities at the school, whose curriculum includes a basic course on computer use. 
Our project team had permanent members responsible for its management and organization, as well as collaborators who worked with the former on specific tasks. Interdisciplinary in makeup, the team comprised professors, staff, technicians and students from the Federal University of Goiás (UFG), the School of Information and Communication (FIC), the School of Visual Arts, and the School of Social Sciences and Anthropology. I was the project coordinator, always working in close conjunction with the A'uwe Xavante, however, both within the project team and with the council of elders, in each successive phase. The coordinating team sought to enable self-management, as well as respect for the traditional A'uwe Xavante manner of decision-making, through ongoing consultation with its council of elders.

The project began in 20I0. The two first years (2010/20I I) were devoted to planning, followed by two years of workshops (2012/20I3). Since 2014, I have monitored the communications media created by the workshops. In 2012 and 2013, project workshops were financed by the Brazilian Ministry of Education (MEC) through a program that supports community outreach projects for the implementation of public policies for social inclusion. One of its financing streams is specifically for digital and ethnic inclusion.

\section{METHODOLOGY}

My research methodology takes as a central reference the method expounded in the book Through Navajo eyes: an exploration in film communication and anthropology (Worth \& Adair, I972). As Banks (2008) affirms, this work provides a clear and well-designed model for empirical research, with lucid and objective methodologies. In addition to this classical reference work, my research employed multiple methods of field research, including interviews, focal groups, actionresearch, participant-observation and ethnographic method, with emphasis on the use of photography and the audiovisual as field observation methods.

In my research, I have opted for the description and qualitative analysis of the material. I examine the process of media development within the framework of Aldeia Digital (Digital Village) project, as well as the results and products it generated. In interpreting the results, I reflect upon and discuss the concepts of social organization involved in media production and indigenous media.

Workshops were developed over the course of 2012 and held monthly, over weekends and holidays. In July 2012, we carried out a workshop whose activities were split between the Sangradouro and San Marcos Indigenous Lands (ILs), separated by a distance of I $27 \mathrm{~km}$. Finally, in July 20 I 3, we ran a workshop that used the Television Studio and video editing computer at the School of Information and Communication of the Federal University of Goiás (FIC-UFG).

Our students were A'uwe Xavante from Sangradouro village, the focal group of our research. We initially issued an open invitation to the entire village, and tried not to limit workshop students to one gender, age group or clan. As 
the project unfolded, it took shape spontaneously as a self-managed, fixed group of students. It was made up of I 5 men between I5 and 25 years of age, divided into four groups. They possessed basic knowledge in computers, acquired in classes taken at the village school.

The workshops led to the production of a blog, a documentary video, nine animated short films using a stop-motion technique, two logos, a series of posters and a Facebook group. This added up to a total of I 3 workshops, I I of which were used as a source of information for my research. The core of my analysis was limited to the material collected in five workshops: blog, posters, animated films (two workshops) and a documentary video. I also analyzed the creation of two logos - one for the Digital Village Project itself and the other for the Organization of Xavante Indigenous Peoples (OPIX).

Over the course of my research, my original goals were expanded due to the interest expressed by other indigenous groups in taking part in the project. In response to this demand, we held workshops in Argola village belonging to the indigenous community of the Terena de Cachoeirinha IL, and in Merure village in the Bororo IL. For the purposes of my research, however, I limited myself entirely to the analysis of Xavante data.

\section{INDIGENOUS MEDIA}

Ginsburg (I99I: I07) defines indigenous media as media produced by indigenous peoples who have been historically dominated by the States of countries such as the United States, Canada and Australia. To this list we can add Brazil, which has sometimes been referred to as the 'fourth world.' Wilson and Stewart (2008: 2) provide us with a definition that speaks of media "conceptualized, produced and/or created by the indigenous people of the world." For Ginsburg (I995: 2 I I), the use of the term "indigenous media" is respectful of the understandings and modes of identification of indigenous producers themselves.

How can the concept of indigeneity be used as a theoretical tool for reflections on indigenous media? According to Wilson and Stewart (2008: 23), indigenous media "articulate and negotiate the meaning of indigeneity in the 2oth century" and, in Ginsberg's view (1993: 369), its "multiple ways [...] emerges from very different social bases for the understanding of [indigeneity] and its representation [...] across cultural and national borders." In other words, the existing set of relational concepts of indigeneity can serve as a point of departure for answering the question posed above. Ginsburg (I995: 216) sees indigenous media as a tool that is implemented by different parties in order to reach an agreement: in other words, it becomes a form of mediation, and has the role of negotiating the boundaries and relationships between different social and ethnic groups, between different cultures and generations within an indigenous community, and between identities and Nation States. Turner (I992: I6) highlights the role of indigenous media "as mediators of social and political activ- 
ity." Barth (I976: I I) asserts that the anthropological literature usually defines ethnic group as - among other things - a population that "integrates a field of communication and interaction" and operates between and across ethnic boundaries. Wilson and Stewart (2008: I8) give salience to ethnic media as a central tool for indigenous peoples' movements and actions in relation to the State and national society.

Many of those who conduct research on indigenous media - Ginsburg (I99I, I993, I995), Turner (I992), Alia (2010), Wilson and Stewart (2008), Michaels (I984, I986), Leuthold (I997) - are unanimous in their view that these media play a key role in the set of criteria, properties or conditions that inhere within indigenous communities, in keeping with concepts that emerge around the notion of "indigeneity." In this sense, indigenous peoples have utilized and appropriated a variety of media for political and cultural purposes, "as new vehicles for internal [inter-ethnic] and external communication, for self-determination, and for resistance to outside cultural domination" (Ginsburg, I99I: 92). Prins (2004: 5I6) and Michaels (I986) refer to these processes as the indigenization of media. For Turner (I992: 5), the global expansion of information technologies and low-cost digital technologies have allowed "the appropriation and use of new technologies on the part of indigenous peoples, to their own ends," especially in the case of peoples who live at a distance from the West, such as aboriginal Australians, Canadian Inuit, and Amazonian native peoples.

In Ginsburg's view (I99I), the appropriation of media by indigenous communities poses questions regarding the positive and negative options for the use of technologies. "Is it indeed possible to develop an alternative practice and aesthetic using forms so identified with the political and economic imperatives of Western consumer culture and the institutions of mass society?" (Ginsburg, I995: 2 I0). On the one hand, we are observing "new modes for expressing indigenous identity through media [...] to serve their own needs and ends" (Ginsburg, I99I: 96). At the same time, "the spread of communications technology [...] threatens to be a final assault on culture, language, imagery, relationship between generations, and respect for traditional knowledge" (Ginsburg, I991: 96).

As the present text should make evident, indigenous media pose challenges to traditional models of communication. Turner (I992) argues that indigenous peoples use media very differently from non-indigenous populations. Molnar (I990: I52) asserts that indigenous peoples see their land as "the center from which information emanates. Their information/communications model is the reverse of the European model, which sees urban cities as the center and remote communities as the periphery". This model of indigenous communication unfolds through what we can refer to as the "indigenous perspective." This involves not only a change in point of view and reference, but also a questioning of policies, power, and the processes of domination and exploitation that remain concealed in the importation and adoption of external models. 


\section{INDIGENOUS MEDIA AS SOCIAL PROCESS}

According to Michaels (I984), the way in which indigenous media are produced, exhibited, and used reflects the social structure of the community from which they emerge, their political system, rules of kinship and other issues related to indigenous society.

In comparison to traditional media and their generally stereotypical ways of representing indigenous communities, indigenous media not only permit other forms of representation but other processes and forms of social organization of production - more vertical and less hierarchical, more inclusive, participatory, collaborative and collective. In Ginsburg's view (I993, I995), the diverse types of indigenous media produced by and with indigenous communities operate across different levels of social, political and economic change and organization. They represent the varied social roles and positions occupied by indigenous communities and the way in which they acquire "visibility and cultural control over their own images" (Ginsburg, I995: 228).

Ginsburg (1993: 378) emphasizes that "the social relations built out of indigenous media practices are helping to develop support and sensibilities for indigenous actions for self-determination", making their concerns visible to the entire world and creating areas of cooperation that connect indigenous producers "at local, national, transnational and international levels" (Ginsburg, I993: 378). From within this framework, the author suggests that the work and social production of indigenous media comprise a new model of cultural production. She proposes the analysis of indigenous media as a complex cultural object and as part of the mediascape (Appadurai, I990) of social relations.

In a pioneering work, Michaels (1984) analyzes the social organization of video production among Australian aborigines. In his article, the author describes kinship relations among media project participants. The genealogy of kinship demonstrates that the people involved were closely related, whether through the maternal or paternal lineage. The communicational division of labor was distributed among these lineages. The author also shows that the major functions of video production, such as directing and camera work, were divided according to criteria inherent to the social structure of aboriginal communities. Hence, cameraman would come from a key individual's paternal line, and the director from the maternal line. The social organization of video production thus observed and respected kinship rules and the ceremonial requisites of aboriginal tradition.

\section{XAVANTE MEDIA}

The Xavante people have a longstanding relationship with media, initially as objects that interested them and, more recently, as relations that they themselves produce. According to Leal (2017), during the I940s, the Xavante became known throughout Brazil due to the publication of numerous articles in the 
mass media, in particular, which recorded the first contacts with the population. One example was the article published in I942 in the magazine O Cruzeiro. Intitled "Enfrentando os Chavantes" (Confronting the Xavante), it included an aerial photo taken by the photographer Jean Manzon in which a group of several Xavante can be seen shooting arrows at an airplane circling above their village. The text reports that arrows hit the plane as it flew some five meters from the ground. With the sponsorship and support of the Brazilian state, the press represented the Xavante as warlike savages.

Leal (2017) observes that the first experience of Xavante use and appropriation of communication technologies in their struggle for rights dates back to the late I970s. At that time, Mario Juruna, the political leader of the San Marcos Indigenous Land, had the idea of using a tape recorder to record government personnel, who would be caught making false promises to return Xavante land to tribal control. Later, using the press, Juruna disseminated the recordings and publicly exposed the government staff as liars (Graham, 20I I). This activism made Juruna quite well known, and in I 982 he became the first and only indigenous person to be elected to Congress. This was a pioneering example of the use of communication technology in the construction of a political career and in relation to the Nation State.

Audiovisual filmmaking is the primary Xavante media and was first put to use in I 997 through the Vídeo nas Aldeias project. The first video was made by Caimi Waiasse, a Xavante man from the Pimentel Barbosa Indigenous Land, and bears the title Tem que ser curioso (One has to be curious). In the film, the Xavante director discusses how he became interested in cinema. The second film was made in I 998 and called Hepari Idub'rada, thank-you, brother. Directed by Divino Tserewahú from the Sangradouro Indigenous Land, it features Divino's own testimony as he thanks his brother for having taught him to use a video camera and make audiovisual productions. This initial series of films provide an interesting insight into an indigenous people's discovery of film and communications media.

In I999, Divino invited Caimi, along with two other Xavante and a Suyá person, to make a documentary on Xavante initiation rituals. The other two Xavante are Bartolomeu Patira from Sangradouro and Jorge Protodi from Pimentel Barbosa. The resulting production was Wapté Mnhõnõ, iniciação do jovem xavante (Initiation of a Xavante Youth), made on the training workshops of the Vídeo nas Aldeias project. The video went on to win five awards: two in Brazil, two in Italy and one in Bolivia. Coelho (2007: 57) states in his master's dissertation that this film represents "the first attempt on the part of a Xavante group to produce an anthropology of themselves, a narrative and audiovisual text on their own ritual." Caixeta de Queiroz (2008: II3) also asserts that in the film Iniciação do jovem xavante, "it is the power of the images and sounds that allow for the production of a true native anthropology." 
In general terms, this production, as well as most of the videos made by Divino, including Wai'á Rini, o poder do sonho (The power of the dream) (200I), Daritizé, aprendiz de curador (The healer's apprentice) (2003), Pi'õnhitsi, mulheres xavante sem nome (Xavante women without a name) (2009) share a common theme: the recording of rituals, whether of social initiation (Wapté Mnhõnõ), cosmology (Wai'á Rini and Daritizé) or womanhood (Pi'õnhitsi). This thematic preference is indicative of how Divino's production and appropriation of media has at its core the goal of disseminating Xavante ritual and notions of culture. In Belisário's words, “Divino's films have embedded within them the sensible dimensions of Xavante experience of ritual [...] ritual and film end up converging on the same spot: the warã - or central patio of the Xavante village" (Belisário, 20I8: I33-I34).

\section{SANGRADOURO VILLAGE POLITICS}

\section{Factions}

According to Paula (2007: 78), factions are "context-related and corporatist social groups that emerge around ephemeral political goals, made up exclusively of men who belong to the elder age group (Iprédu)." For Maybury-Lewis (I984), a faction is made up of a lineage and those who support it, the latter element consisting of members of another lineage from the same clan, isolated individuals or even lineages belonging to a different clan. They are temporary political groupings that come together around the dichotomous categories found in clans and lineages. According to Lopes da Silva (I986: 246), the ground from which factions spring are "groups with common paternal ancestry". The Xavante term for people of the same faction is watsiwadi, a term that can be translated as "my people."

In Sangradouro, when we began the Digital Village Project, we were informed that there was a split in the village. According to project members, this split dated back to $20 \mathrm{I}$, during the election of the leaders of the youths who were set to take part in the initiation ritual. Tsererureme 'dzai'wa, a man from the Pörredza'õnõ clan, presented his son to the men's council as a candidate to lead the initiation rites. The Pahöri'wa leader is the most important ritual and ceremonial position in Xavante society. It is the exclusive function of the Pö'redza'õnõ clan, specifically of the Pahöri'wa lineage and the leader of its age group during the ritual, noting here that it is important to distinguish between the Pahöri'wa lineage and the leader of the initiation ritual, also referred to as Pahöri'wa. In Sangradouro village, the major lineages are the Pahöri'wa of the Pörredza'õnõ clan and the Tebe of the Öwawē clan.

On this occasion, the council elected four leaders for the initiation rites rather than the customary two. This outcome displeased one group of people who subsequently broke off their alliance with the dominant faction and transferred their support to the opposition. The results of the election thus weakened 
the dominant group, which lost supporters. In turn, the opposition was strengthened, bringing the discontented and those aspiring to the chiefdom together. It may well be that the problem of the election of the Pahöri'wa had been used as pretext to weaken the dominant faction.

According to Maybury-Lewis (1984), in the Xavante village of San Domingos (today Pimentel Barbosa), there was only one Pahöri'wa leader who was not of the same lineage as the chief. The chief kept the ceremonial position among his own sons, whose status, in turn, came from their father's position as chief. Each of his sons belonged to a different age group (generation). Control over age groups establishes the chief's power at all levels of the community and represents a pattern of authority. In turn, the chief's position is the sum of the status of those of his children who retain his prestige. In this case, ensuring that his children occupied leadership positions was a political strategy enabling him to maintain his own prestige.

Perhaps this is the same case in Sangradouro. Having a son occupy an important ceremonial position is a clear strategy for maintaining the prestige of a father. Project participants confirmed the existence of disputes over the position of chief within the village.

One external factor that intensified factionalism was the official process of demarcation of the indigenous land (the Sangradouro IL). The reservation was officially established in I99I, yet the Xavante accused landowners holding property near the Sangradouro village of trespassing. This induced the $\mathrm{Na}-$ tional Indigenous Foundation, the Brazilian government institution responsible for the indigenous land demarcation, to create a technical committee that would verify the situation and evaluate whether invasion had occurred. Over the course of this extended process, which began in 2003 and has not yet been concluded, the Xavante people and landowners have been engaged in conflict. The FUNAI headquarters in the town of Primavera do Leste was the target of an arson attack, and there have been cases of assault, shootings and even murders in the vicinity. But neither has the conflict led to a unified position among the Xavante themselves. Some Xavante have aligned with landowners and their interests, a fact that serves to reinforce conflict with the latter, as well as internal divisions among Sangradouro village members.

According to participants in the Digital Village Project, for the first time in the history of Sangradouro, the village now has two chiefs. Maybury-Lewis (I984) noted that division into two factions is a basic fact of the Xavante political system. It guides behavior and is a basic element of the Xavante political system. Factions are always in dispute over power, political prestige and the most important political function, the position of chief. In those cases where there is no dominant faction in a village or over a particular period of time, each faction may have its own chief. Based on this factionalism, it may be fair to suppose that there have always been both dominant and oppositional fac- 
tions within Sangradouro village. A change occurred during the period when the Digital Village Project was taking place in which the opposing faction gradually accumulated more power and prestige, even to the point of electing its own chief and publicly declaring its rival stance.

In Sangradouro, when men began to talk about the dispute between the factions, they posed this as something unnatural, evil even, and wrong - being ambitious for power was qualified as a defect and as something that eroded communion, unity and peace within the village. However, it should be recognized that those expressing this view were usually members of the old dominant faction. Members of the new oppositional faction would agree with MayburyLewis's (I 984) classification of this type of dispute as a struggle for justice. In Xavante tradition, new oppositional factions generally move on to form new villages. The fact that the new oppositional faction decided to remain in the Sangradouro village was an aggravating factor, I suggest, evincing a transformation in the traditional form of resolving conflicts within the Xavante political system.

At the end of 20I2, we held a small graduation ceremony and handed out certificates to those who took part in our project. At the center of the village, teachers from the village school have the opening speeches: Oswaldo Buruwe Marãdzuhõ, member of the Pöredza'õnõ clan, and Bartolomeu Patira Pronhopa, the head of 'my own' domestic group, from the Öwawe clan, and aligned with the old dominant group. They were followed by my own speech. While I was giving my talk, the chief of Don Bosco village, brother of the chief of the new oppositional faction, interrupted me, accusing me of not allowing his son to take part in the project and thereby favoring the old dominant faction. I attempted to continue my talk, but he was visibly very upset. I had to bring my speech to an abrupt end in an attempt to calm him down and explain the situation. Yet that endeavor proved to no avail and the incident sadly ended in a threat of aggression.

According to Maybury-Lewis (I984), many of the problems that arise between individuals are in fact caused by disputes between groups and factions. A personal disagreement attributed to particular political factions, as in the example cite above, requires the support of the factions in order to be formally recognized and thereby dealt with through the due process of law, conducted through the men's council. All the personal disputes judged by the council become a factional issue. In such cases, factions act as 'legal persons.' In our specific situation, the personal dispute in question did not reach the men's council, indicating that the incident was not endorsed by existing factions. Yet the public accusation made - that I had benefitted one faction in detriment to the other - serves as evidence here to reinforce the argument that the Digital Village Project was appropriated by the longstanding dominant faction. 


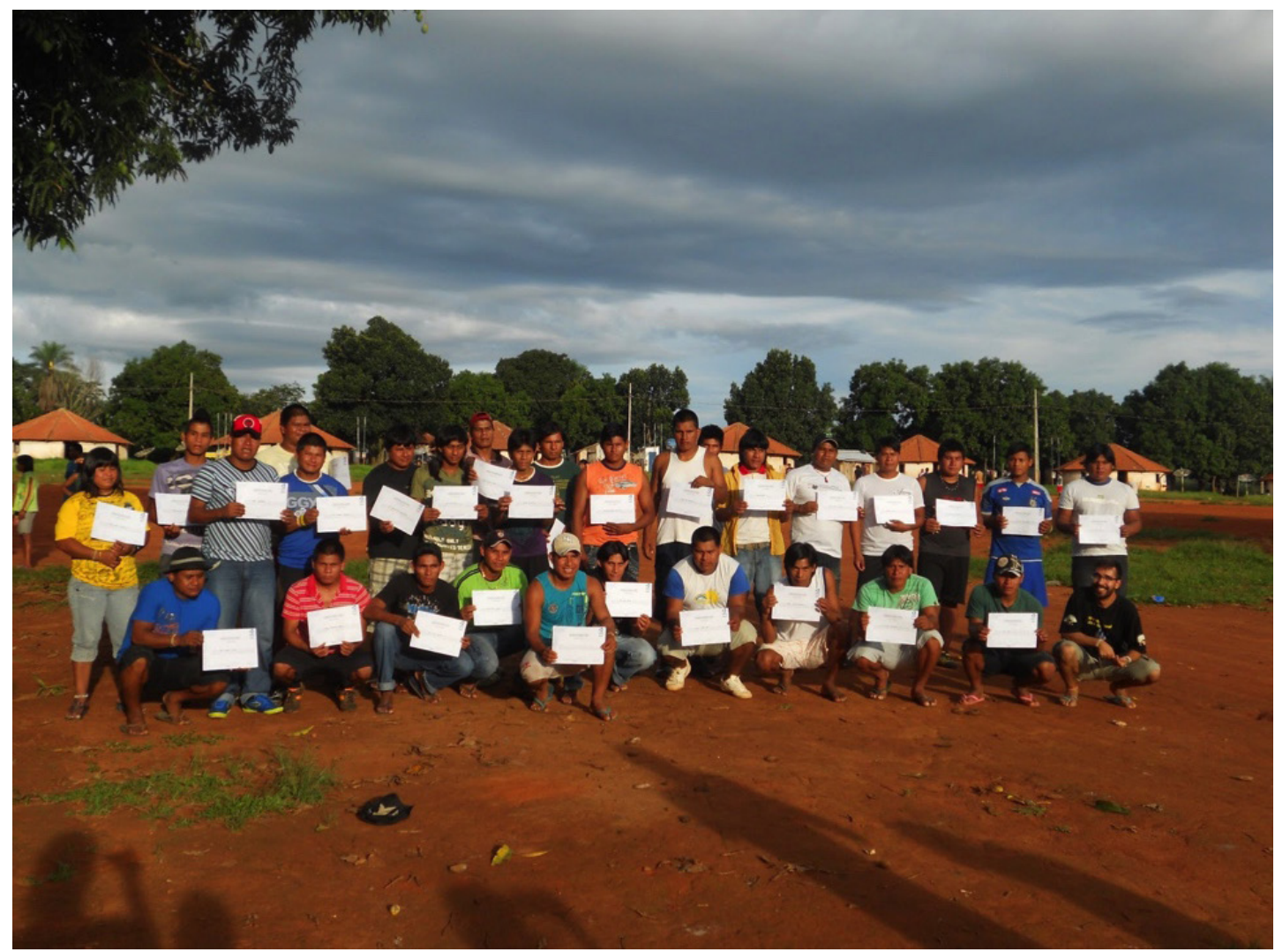

Image I

Handing out certificates to project participants Source: Personal photographic archive.

The irruption of this conflict could be interpreted as recognition of the division in Sangradouro village and the last stage in a processual chain of events, clearly evoking Turner's (I996) notion of 'social drama'. For Turner, the concept of social drama refers to:

a 'temporal structure' in events, and this structure cannot be understood in isolation from the series of synchronic profiles which make up the structure of a social field at every significant point of arrest in the time flow [...] represented a complex interaction between normative patterns laid down in the course of deep regularities of conditioning and social experience, and the immediate aspirations, ambitions and other conscious goals and strivings of individuals and groups (Turner, I996: XXI-XXII).

Following Turner (1996: 92) and his notion of social drama, we can divide the political conflict in Sangradouro village into a social process with four recognizable stages: I. Breach, where we can clearly locate the principle of the 
division of Sangradouro village into factions and the election of the Pahöri'wa; 2. Crisis, marked by the intensified factionalism deriving from the demarcation of the Sangradouro IL and the conflict with landowners; 3. Redressive action, marked by the peace agreement reached by the faction chiefs and our efforts to use the Digital Village Project and communications media as tools for conflict mediation with the reintegrative goal of resolving the political disputes; 4 . Recognition of a schism. In this case, the disagreement manifested by the Don Bosco village chief served as public confirmation of the Digital Village Project's appropriation by the old dominant faction.

\section{Chiefs}

Throughout the development of the Digital Village Project, the chief of the old dominant faction was Alexandre Tsereptsé. Alexandre is a member of the Pö'redza'õnõ clan and the Pahöri'wa lineage. Alexandre's father, Pedro Toroibu, is considered the founder of Sangradouro village. In I957, Pedro led a group coming from the Xavante Parabubure Indigenous Land to what is now Sangradouro. Considering this historical fact, Alexandre's family has always been alternately involved in the leadership of Sangradouro village. Alexandre is also the father of Divino Tserewahú Tsereptsé, a man who participated in the Digital Village Project as editing instructor in our video documentary workshop. This situation is consistent with the explanation given to me by Francisco Tserene'ewe Tsipibu, head of the Maribu village, that all chiefs must be from the Pö'redza'õnõ clan.

The chief of the opposition faction is Domingos Mãhoro'e'’̃, a member of the Öwawē clan and the Tébe lineage. Domingos is married to the sister of a man named Inacio, whom we referred to above in relation to the problem of the Pahöri'wa election and the origin of factional divisions. Domingos's family is from the village of Don Bosco, located in the Sangradouro Indigenous Land. This is an important factor, since Domingos's origin in another Sangradouro village changes the way in which he is seen in Sangradouro itself. MayburyLewis's work (I984) has already provided an explanation of the relationships that connect factions and villages. The Xavante have the custom of identifying communities by their dominant factions. Domingos's family belongs to the dominant faction in Don Bosco village. For Maybury-Lewis (1984), the basis of the relationship between persons of different villages is grounded in bellicosity. In this light, Don Bosco village was identified by the old dominant faction of Sangradouro as a rival. Furthermore, Domingos worked for the FUNAI for a long time. He was the regional coordinator of its activities in the town of Primavera do Leste, the headquarters from which the entire Sangradouro IL is administrated. He has also travelled throughout Brazil and even been abroad (to Italy) as a Xavante representative. 
According to Bartolomeu Patira Pronhopa, there are two types of Xavante politics: internal and external. We could assert that Alexandre is the chief of internal Sangradouro politics, given the history of dominance of his faction within the Xavante political system, while Domingos represents the Xavante people in their relationship with the exterior, the 'others,' 'whites' or Brazilian society in general, using these external relations to acquire prestige and build his own internal political career. Maybury-Lewis (I984) had already noted changes in the position of chief and the influence gained as coordinator of the Indian Protection Service (today's FUNAI) in the village where he worked, almost to the point of substituting the former. In existing custom, the chief of each faction possesses his own men's council, his warã (village center) and distinctive rituals. In $20 \mathrm{I}$, each faction held its own initiation rites.

\section{MANAGEMENT, ORGANIZATION AND STRUCTURE OF THE DIGITAL VILLAGE PROJECT}

In the development of Digital Village workshops in Sangradouro, students were divided into working groups. The animated film workshop was the first, splitting students into five groups. This was followed by the documentary video workshop, which divided its participants into two groups. Finally, the second animated film workshop split its students into the four groups that have been maintained until the present. In this article, I restrict myself to analysis of the last and current training program. Group divisions have enabled self-management, thus restricting my role to the request to form groups. The criteria used by members to form them have not yet been studied. In Table I below I present the clans to which group members taking part in the Digital Village Project belong.

\begin{tabular}{c|c|c} 
& Pöredza'õnõ & Öwawe \\
\hline Group I & 3 people & I person \\
\hline Group 2 & 4 people & - \\
\hline Group 3 & 3 people & - \\
\hline Group 4 & 3 people & I person \\
\hline
\end{tabular}

Table I

Clans of Digital Village group members Source: Author's own field data. 
Initially, the large number of people coming from the Pö'redza'õnõ clan attracts our attention and seems to suggest a certain 'dominance' on its part, since all the members of groups two and three belong to it. This could indicate that these groups are organized according to 'moieties,' yet the presence of members of the Öwawe clan in groups one and four obliges us to dig more deeply into the reasons for their presence. Giaccaria (2000: 145) notes that the Pörredza'õnõ clan may be considered 'dominant' in the majority of Xavante villages, controlling the main political and ritual functions. For Maybury-Lewis (I984), when the dominant faction in a particular village is mostly formed by members of one particular clan, the Xavante identify this community or village as belonging to it.

Throughout my research in Sangradouro village, I was always received and accommodated in the home of a domestic group of the Öwawe clan. This led me to develop more frequent social relations with people belonging to it, indeed to the point that people in the village began to identify me with this particular family and their respective clan. Such personal relations might initially explain the presence of the Öwawe in group I, a member of the same family group.

In the planning stages of the Digital Village Project, during one of the meetings in the center of the village with the men's council, I assumed the commitment to stay out of the dispute between the two factions and to guarantee the participation of members of both. On this occasion, faction chiefs agreed to a 'truce,' which was even sealed with a handshake. During the first project workshops, we issued an open invitation to the entire village, enabling the participation of 50 people from both factions. In the blog workshop, during the first activity leading to publication of content on I4/O2/20I 2,3 I was taken by surprise when students included a short note of support for the chief of the old dominant faction, Alexandre Tsereptsé. This public assertion of factional membership on the part of the group of students using the blog served to confirm the hypothesis that the Digital Village Project was appropriated by the old dominant faction and that media was used in the political conflict between factions. In the following workshops, the number of students taking part dropped and its participants became stabilized as a fixed group. As it turned out, it seems my attempt to avoid becoming embroiled in the conflict between the factions and not to interfere in the shaping of the groups participating in the Project left an open and contested space: this was then occupied by the old dominant group with Alexandre at its head. My argument is that factions fought over and used the Digital Village Project as a strategy to win power and prestige within a situation of conflict. This did not occur to me while I was involved in my fieldwork. Rather, it was only afterwards, during the period in which I began to analyze and reflect upon my data, that this discovery came to me, a consequence of my research. 


\section{The leader of the Digital Village Project}

The four groups of the Digital Village Project each chose a coordinator, one of whom became the overall leader of the project. The choice was made by group members, using criteria I would like to tease out and explore further.

The general coordinator of the Digital Village Project is Natal Anhahö'a Tsere'ruremé. Natal is from the Pö'redza'õnõ clan and belongs to the Pahöri'wa lineage, the same as Alexandre. In fact, Natal is Alexandre's nephew and Domingos's son-in-law, married to his daughter. Through personal communication with Bartolomeu, I learned that Natal was being prepared to become a leader.

According to Maybury-Lewis (I984), the route to leader status is a long one that actually begins with the initiation rites carried out while youths are living in the house of the single men (referred to as Hö in the Xavante language). During this period, young people are groomed for their ability to exercise leadership, including practices that young men of the chief's lineage are engaged in from childhood onwards. These influential members of the dominant faction are referred to in Xavante as ĩdzú. In general terms, all members of the chief's lineage are potential leaders. Some ĩdzú also accumulate the ceremonial position of Pahöri'wa, leader of the youths in the initiation ritual. Others become leaders of their age-class, without necessarily enjoying the honorable title of ĩdzú. The title in itself does not confer prestige: acquisition of the latter requires people to possess a combination of qualities, including self-assertiveness (demonstrating leadership in community activities), speaking ability (being a good orator), physical ability (being a good runner and hunter), and having ceremonial knowledge (as a good singer and dancer). The ĩdzú status demands a combination of prestige with the political influence of the dominant faction.

Before taking part in the Digital Village Project, Natal was a system software teacher at the village school. He later became a student at the Sin Fronteras International Workshop of Documentary Film, organized by FIC-UFG (Federal University of Goiás) and the School of Cinema and Visual Arts of La Paz, Bolivia. During the workshop, Natal acquired knowledge of audiovisual production, working alongside Divino, his uncle and son of the chief of the old dominant faction. Natal was engaged in all phases of the Digital Village Project, from its conception to teaching video camera usage in the documentary workshop, and, finally, as the project's general coordinator. It is worth noting here some of the internal and external factors involved in Natal's election as coordinator or 'leader' of the Digital Village Project. Natal was being prepared "from within" to take on a position as leader. This status made it possible for him to leave the village and take part in outside projects like Digital Village. In turn, participation in outside projects awarded him more prestige within the village. Increased power on the inside then enabled him to assume leadership positions within outside projects such as our own. While the basis for the production of his external leadership sprung from the internal dynamics of the Xavante political 
system, external factors such as participation in the Digital Village Project became instrumental in the construction of his internal political career.

\section{Coordinators}

In addition to Natal, the coordinators of the other three groups of the Digital Village Project are from the Pahöri'wa lineage, the same as Alexandre and Natal. According to one of the coordinators, Alessio Tseredzati Tsiruwewe, all the project members who came from the Pöredza'õnõ clan belong to the Pahöri'wa lineage. All the coordinators and members from the Pö'redza'õnõ clan are from the same lineage, therefore, and allies of the old dominant faction to which Alexandre belongs.

Another important datum on group coordinators is that they all belong to the Iprédu ité age categories of 'mature men.' As stated earlier, Xavante society is divided into hierarchically organized age groups, from oldest to youngest. Age-classes are made up of those who have lived together during the period prior to initiation rites, spanning some five years, in 'the house of those who are single" (Hö) and are therefore initiated together, as well as married together in a collective ceremony. There are eight of these age-classes, forming, as it were, a continuous cycle of approximately 48 years. The age categories indicate the stages through which every Xavante should pass over the course of a lifetime. They become groups of people who have certain socially recognized attributes in common, thereby instituting a form of a social hierarchy.

Age classes and categories are divided into two moieties in accordance with the binary ordering of Xavante thought. Alternate age classes belong to the same moiety and cooperate with one another. Consecutive age classes belong to different moieties and are thus competitors. In Table 2 I present age categories and age classes of the Sangradouro village, divided in two columns, for the purpose of illustrating how cooperation and competition are established between moieties. 


\begin{tabular}{|c|c|c|c|c|}
\hline $\begin{array}{l}\text { Social condition or } \\
\text { life cycle stage }\end{array}$ & \multicolumn{2}{|c|}{$\begin{array}{l}\text { Sequence of male age } \\
\text { categories divided in } \\
\text { moieties }\end{array}$} & \multicolumn{2}{|c|}{$\begin{array}{l}\text { Sequence of age classes } \\
\text { divided in moieties }\end{array}$} \\
\hline Baby & \multicolumn{2}{|l|}{ Ai'utē } & \multicolumn{2}{|c|}{ Absence of age classification } \\
\hline Child & \multicolumn{2}{|l|}{ Watebremi } & & \\
\hline Adolescent & \multicolumn{2}{|l|}{ Ai'repudu } & & \\
\hline Single youth & \multicolumn{2}{|l|}{ Waptē } & \multicolumn{2}{|l|}{ Anarowa } \\
\hline Youth & & Ritéi'wa & & Nodzö’u \\
\hline Mature youth & Danhohui'wa & & Abare'u & \\
\hline \multirow{2}{*}{ Mature man } & & Iprédu ité & & Etepá \\
\hline & \multicolumn{2}{|l|}{ Iprédu } & \multicolumn{2}{|l|}{ Tirowa } \\
\hline \multirow{4}{*}{ Elder } & \multirow{4}{*}{\multicolumn{2}{|c|}{ Ihire }} & & Hötörã \\
\hline & & & Ai'rere & \\
\hline & & & & Tsada'ro \\
\hline & & & Anarowa brada & \\
\hline
\end{tabular}

Table 2

Xavante age-classes and categories in Sangradouro (20I2) Source: Author's own field data.

Table 3 illustrates the age categories that were found among members of the Digital Village Project.

\begin{tabular}{l|l} 
Social condition or life cycle stage & Age categories \\
\hline Youth & Ritéi'wa \\
\hline Mature youth & Danhohui'wa \\
\hline Mature man & Iprédu ité \\
\hline
\end{tabular}

Table 3

Age-categories of Digital Village Project members

Source: Author's own field data. 
Graham (I986) asserts that youths (ritéi'wa) are considered an intermediate stage in the Xavante life cycle. They are not children attached to the domestic sphere, but are not yet considered adults linked to the social environment of mature men, at the 'center' of the village (warã). In Sangradouro, mature men (Iprédu) and youths (ritéi'wa) have separate warã. Youths have their own warã as they are still unable to take part in the political life of the warã of the mature men. Youths do not take part in politics. Participation in Xavante politics begins when one reaches the category of mature youth (danhohui'wa) and reaches its apex with the mature man (iprédu). Factions are formed exclusively by persons who belong to the age category of mature men.

Analysis of the power relations between the age categories of project members allows us to observe the gradual transition process from youths, for whom friendship, companionship and solidarity prevail, to the stage of the mature men - a phase that marks the beginning of participation in and commitment to village politics and factions. Absence of faction membership among youths (ritéi'wa) and 'mature youths' (danhohui'wa) allow the young to be 'manipulated' by the mature men of their lineage who have political interests in mind. The coordinators of the Digital Village Project groups all belong to the Iprédu ité category of mature men. The commitment that these coordinators have with the old dominant faction becomes evident when they take on the role of project group leader. Hierarchy and relations of domination between age categories provide the political power needed to control inferior categories. In general, we can note that as men reach higher age categories, they acquire greater power and political prestige. In the case of the groups in our project, leadership became one way in which the old dominant group sought to guarantee control over the project. My fieldwork enabled me to perceive the political implications that the hierarchy present in age categories has for power relations. In general, the elderly have more political prestige than young people, except for those who become leaders.

\section{CONCLUSIONS}

After examining the social and political context of Sangradouro village, it becomes possible to explain the social organization of Xavante media production in the Digital Village Project. The Xavante political system, political conflict and power disputes between factions had major impact and influence, and determined the formation of groups during the project. Factions fought over the project and used it as a political strategy for attaining prestige and power within their own political struggles. The old dominant faction appropriated the project and used its media for the purposes of its own political struggle, since the groups that took part in the project were largely made up of members of the faction in question. Choice of group leaders was based on criteria proper to the Xavante social structure and political system. The use and meaning of 
media within the Sangradouro community were socially, politically and culturally constructed. Thus, the local dynamics of the Xavante appropriation of digital media and the social organization of the groups making up the Digital Village Project reinforced the continuity of the Xavante social structure and the influence of its political system in the social, political and power relations of Sangradouro village. Finally, we must conclude that the project and the media it produced were capable neither of solving nor of mediating the village's internal political conflicts. Quite to the contrary, they reinforced the struggle of one of the factions to assert its own control over the project.

The results of my analysis of the social organization of Xavante media production generate a hypothesis for future research. I suggest that the groups that participate in the Digital Village Project were put together not only on the basis of the Xavante political system but also their kinship system. Lineage becomes the point of encounter between the political and kinship systems. A lineage is a group of blood relatives with common paternal ancestry, and also it constitutes the basis for the formation of factions. All members of the project constructed through the Pahöri'wa lineage are descendants of the same ancestry. In the absence of a genealogy that could help me delve deeper into this hypothesis, I am obliged to leave this task to future research.

Received on 20/aug/20I9 | Revised on 04/apr/2020 | Approved on I/may/2020

Rafael Franco Coelho holds a bachelor's degree in graphic design from UNESP, a master in arts from Unicamp and a PhD in digital communication from the Universidad Autònoma de Barcelona, including a sandwich doctoral course at the Institute of Social and Cultural Anthropology of the University of Oxford (United Kingdom). He is assistant professor at the Faculty of Information and Communication of the Federal University of Goiás, a researcher for the Institute of Communication (InCom-UAB) and collaborator with the International Study Group on Communication and Culture. He has experience in visual communication and audio-visual production, working primarily in the areas of indigenous media and cinema, and ethnographic documentaries. His publications include "Medios digitales y movimiento indígena en Brasil: la organización de los pueblos indígenas Xavante," "El proyecto Aldea Digital: metodología de investigación de los medios de comunicación Xavante en el Brasil Central" and the coauthored text "Medios de Comunicación e Identidad A'uwē Xavante: Mito, ritual y política en el Brasil Central."e Identidad A'uwē Xavante: Mito, ritual y política en el Brasil Central". 


\section{NOTES}

I Translator: Miriam Adelman.

2 For further information on the history of Sangradouro village, see Divino Tserewahú's documentary Sangradouro, available online on the Video nas Aldeias website: <http:// www.videonasaldeias.org.br/2009/video.php?c=76>.

3 See <http://aldeiasangradouro.blogspot.com.es/2012/02/ apresentacao-inaratadze.html>. Consulted September 22, 2015 .

\section{BIBLIOGRAPHY}

Alia, Valerie. (2010). The new media nation: indigenous peoples and global communication. New York/Oxford: Berghahn Books.

Appadurai, Arjun. (1990). Disjuncture and difference in the global cultural economy. Theory Culture Society, 7/295. Banks, Marcus. (2008). Using visual data in qualitative research. London: Sage.

Barth, Frederik (ed.). (1976). Los grupos étnicos y sus fronteras. La organización social de las diferencias culturales. Ciudad de México: FCE.

Belisário, Bernard. (2018). Desmanchar o cinema: pesquisa com filmes xavante no Wai'a Rini. Tese de Doutorado. PPGCOM/Universidade Federal de Minas Gerais.

Caixeta de Queiroz, Ruben. (2008). Cineastas indígenas e pensamento selvagem. Devires, 5, p. 98-I25.

Coelho, Rafael Franco (2007). Iniciação: um olhar videográfico sobre mito e ritual Xavante. Dissertação de mestrado. PPGA/Universidade Estadual de Campinas.

Giaccaria, Bartolomeo. (2000). Xavante - ano 2000: reflexões pedagógicas e antropológicas. Campo Grande: Universidade Católica Dom Bosco.

Ginsburg, Faye (1995). Mediating culture: indigenous media, ethnographic film, and the production of identity. In: Deveraux, Leslie \& Hillman, Roger (eds.). Fields of vision: essays in film studies, visual anthropology and photography. Berkeley: University of California Press, p. 256-29o. 
Ginsburg, Faye (1993). Embedded aesthetics: creating a discursive space for indigenous media. Cultural Anthropology, 9/2.

Ginsburg, Faye. (I99I). Indigenous media: faustian contract or global village? Cultural Anthropology, 6/I, p. 92-II2. Graham, Laura Rea. (20II). Citando Mario Juruna: imaginário linguístico e a transformação da voz indígena na imprensa brasileira. Mana, I7/2, p. 27I-3I2.

Graham, Laura Rea. (I993). A public sphere in Amazonia? The depersonalized collaborative construction of discourse in Xavante. American Ethnologist, 20/4, p. 7I7-74I.

Graham, Laura Rea. (I986). Three modes of Shavante vocal expression: wailing, collective singing, and political oratory. In: Sherzer, Joel \& Urban, Greg (eds.). Native South American discourse. Berlin: Mouton de Gruyter, p. 83-II8.

Leal, Samuel. (20I7). Dias de índio: performance, estética, política e a presença dos Xavante na televisão da década de I980. Cadernos de Arte e Antropologia [online], 6/2, posted online October I, 2017, consulted Feb. 24, 2020. URL: <http://journals.openedition.org/cadernosaa/I298>; DOI: <https://doi.org/I0.400o/cadernosaa.I298>.

Leuthold, Steven. (1997). Native media's communities. American Indian Culture and Research Journal, 2I/2, p. I65-I95. Lopes da Silva, Aracy. (I986). Nomes e amigos: da prática xavante a uma reflexão sobre os Jê. São Paulo: FFLCH/USP.

Maybury-Lewis, David. (I984). A sociedade xavante. Rio de Janeiro: Francisco Alves.

Michaels, Eric. (1986). Aboriginal invention of television: Central Australia 1982-86. Canberra: Australian Institute of Aboriginal Studies.

Michaels, Eric. (1984). The social organization of an Aboriginal video workplace. Australian Aboriginal Studies, I, p. 26-34.

Molnar, Helen. (I990). Aboriginal broadcasting in Australia: challenges and promises. The Howard Journal of Communications, 2/2, p. I49-I69.

Paula, Luís Roberto de. (2007). Travessias - Um estudo sobre a dinâmica socioespacial xavante. Tese de Doutorado. PPGAS/ Universidade de São Paulo. 
Prins, Harald E. L. (2004). Visual anthropology. In: Biolsi, V. (ed.). A companion to the anthropology of American Indians. Malden: Blackwell, p. 506-525.

Turner, Victor. (1996). Schism and continuity in an African society: a study of Ndembu village life. Oxford/Washington, D.C.: Berg.

Turner, Terence. (I992). Defiant images: the Kayapo appropriation of video. Anthropology Today, 8/6, p. 5-16.

Wilson, Pamela \& Stewart, Michelle. (2008). Global indigenous media: cultures, poetics, and politics. Durham: Duke University Press.

Worth, Sol \& Adair, John. (1972). Through Navajo eyes: an exploration in film communication and anthropology. Bloomington: Indiana University Press. 


\section{Palavras-chave \\ Mídia indígena; organização social da produção midiática;} terras baixas sul-americanas;

Xavante.

Keywords

Indigenous media; social organization of media

production; Lowland South America;

Xavante.
PROJETO ALDEIA DIGITAL: UMA ANÁLISE DA ORGANIZAÇÃO SOCIAL DA PRODUÇÃO DE MÍDIA XAVANTE NO BRASIL CENTRAL

\section{Resumo}

Neste artigo, analiso a organização social da produção de mídia xavante no projeto Aldeia Digital, as características e especificidades sociais da sociedade xavante refletidas na organização do projeto Aldeia Digital. Para explicar como os alunos do projeto se organizaram em grupos, relaciono esses grupos com a estrutura social e o sistema político xavante. A hipótese do artigo é de que a formação dos grupos do projeto e a interação de seus membros foram estabelecidas a partir de categorias presentes na estrutura social xavante. Nesse sentido, a introdução da mídia e dos meios de comunicação na comunidade não foi suficiente para transformar as relações sociais na aldeia xavante de Sangradouro.

\section{THE DIGITAL VILLAGE PROJECT: EXAMINING THE SOCIAL ORGANIZATION OF XAVANTE MEDIA PRODUCTION IN CENTRAL BRAZIL}

Abstract

In this article, I analyze the social organization of Xavante media production during the Digital Village Project, and explore how student involvement in the latter reflects the social characteristics and specificities of the Xavante community. To explain how project participants organized themselves into groups, I connect these groupings to the Xavante social structure and political system. My hypothesis is that the formation of the groups making up the project and the interaction of their members were established through categories already present in Xavante social structure. In this sense, we can conclude that the introduction to media production in the community is not enough to change the social relations prevailing in Sangradouro village. 